Cita: Rodrigues, F., Neiva, H.P., Marinho, D.A., Mendes, P., Teixeira, D.S., Cid, L., Monteiro, D. Assessing Need Satisfaction and Frustration in Portuguese Exercise Instructors: scale validity, reliability and invariance between gender. Cuadernos de Psicología del Deporte, Vol 19(1), 233-240

\title{
Assessing Need Satisfaction and Frustration in Portuguese Exercise Instructors: scale validity, reliabity and invariance between gender
}

\section{Evaluación de la satisfacción y la frustración de las necesidades en los instructores portugueses de ejercicios: validez de escala, confiabilidad e invariancia entre los géneros}

\section{Avaliando a Satisfação e Frustração das Necessidades em Português Instrutores de Exercício: validade da escala, fiabilidade e invariância entre géneros}

\author{
Rodrigues, Filipe, ${ }^{1,5}$, Neiva, Henrique Pereira ${ }^{1,5}$, Marinho, Daniel Almeida ${ }^{1,5}$, Mendes, Pedro ${ }^{2}$, Teixeira, \\ Diogo Santos ${ }^{3}$, Cid, Luís ${ }^{4,5}$, Monteiro, Diogo ${ }^{4,5}$ \\ ${ }^{1}$ Beira Interior University, Department of Sports Science, Covilhã, Portugal, ${ }^{2}$ Instituto Politécnico de Castelo Branco, Castelo \\ Branco, Portugal, ${ }^{3}$ Lusófona University, Lisbon, Portugal, ${ }^{4}$ Sport Science School of Rio Maior (ESDRM-IPSantarém), Rio \\ Maior, Portugal, ${ }^{5}$ Research Center in Sport Sciences, Health Sciences and Human Development (CIDESD), Vila Real,
} Portugal

\begin{abstract}
Objective: The aim of the present study was to validate the Basic Psychological Need Satisfaction and Frustration Scale in Exercise for fitness instructors. Methods: Data from 477 exercise professionals (319 males, 158 females) was collected. Results: CFA supported the adapted and validated six-factor model: $[\chi 2(237)=1096.796, \chi 2 / \mathrm{df}=4.63$; $\mathrm{B}-\mathrm{S} \mathrm{p}<.001, \mathrm{CFI}=.930, \mathrm{TLI}=.918, \mathrm{SRMR}=.0366, \mathrm{RMSEA}=.079(\mathrm{CI} 90 \%=.069, .089)]$, assessing satisfaction and frustration of basic psychological needs in Portuguese exercise professionals. Moreover, the analysis revealed acceptable composite reliability, and construct validity of the adapted version. Results revealed nomological validity, as well as invariance between male and female. No differences were found across latent means, and magnitude effects were trivial between gender. Conclusion: These results support the use of the adapted scale in exercise professionals, showing measurement invariance between gender. This scale is able to measure how exercise professionals experience satisfaction and frustration of basic needs when prescribing exercise to individuals in fitness context.
\end{abstract}

Keywords: self-determination theory, exercise, basic needs, interpersonal behaviors, exercise instructors.

\section{RESUMEN}




\section{Rodrigues, F., Neiva, H.P., Marinho, D.A., Mendes, P., Teixeira, D.S., Cid, L., Monteiro, D.}

Objetivo: El objetivo del presente estudio fue validar la Escala de Satisfacción y Frustración de Necesidades Psicológicas Básicas en el Ejercicio para instructores de ejercicio físico. Métodos: Se recopilaron datos de 477 profesionales del ejercicio (319 hombres, 158 mujeres). Resultados: CFA apoyó el modelo de seis factores adaptado y validado: $[\chi 2(237)=1096.796, \chi 2 / \mathrm{df}=4.63 ; \mathrm{B}-\mathrm{S} \mathrm{p}<.001, \mathrm{CFI}=.930, \mathrm{TLI}=.918, \mathrm{SRMR}=.0366, \mathrm{RMSEA}$ $=.079(\mathrm{CI} 90 \%=.069, .089)]$, evaluando la satisfacción y la frustración de las necesidades psicológicas básicas en los profesionales del ejercicio portugués. Además, el análisis reveló una validez en la confiabilidad compuesta, constructo y nomológica aceptables de la versión adaptada, así como invariabilidad entre hombres y mujeres. No se encontraron diferencias entre las medias latentes, y los efectos de magnitud fueron triviales entre los géneros. Conclusión: estos resultados apoyan el uso de la escala adaptada en los profesionales del ejercicio, que muestran la invariancia de la medición entre los géneros. Esta escala es capaz de medir cómo los profesionales del ejercicio experimentan la satisfacción y la frustración de las necesidades básicas, y cómo regulan los comportamientos interpersonales.

Palabras-clave: teoría de la autodeterminación, ejercicio, necesidades básicas, comportamientos interpersonales, instructores de ejercicio.

\section{RESUMO}

Objetivo: O objetivo deste estudo consistiu na validação do Basic Psychological Need Satisfaction and Frustration Scale in Exercise em instrutores de fitness. Métodos: Recolhemos dados de 477 profissionais de exercício físico (319 masculino, 158 feminino). Resultados: A análise CFA suporta o modelo de 6-factores adaptado e validado: [ $\chi 2(237)$ $=1096.796, \chi 2 / \mathrm{df}=4.63 ; \mathrm{B}-\mathrm{S} \mathrm{p}<.001, \mathrm{CFI}=.930, \mathrm{TLI}=.918, \mathrm{SRMR}=.0366, \mathrm{RMSEA}=.079(\mathrm{CI} 90 \%=.069, .089)]$, avaliando a satisfação e frustração das necessidades psicológicas básicas em instrutores profissionais portugueses de exercício físico. Além disso, a análise revela fiabilidade compósita aceitável e validade dos construtos da versão adaptada. Os resultados revelam validade nomológica, bem como invariância entre sexo masculino e feminino. Não foram encontradas diferenças entre as médias latentes, e a magnitude dos efeitos foi trivial entre géneros. Conclusão: Estes resultados suportam o uso desta escala adaptada em profissionais do exercício físico, mostrando ser invariante entre géneros. Esta escala é capaz de medir como os técnicos profissionais de exercício físico experienciam a satisfação e frustração das necessidades básicas aquando da prescrição de exercício físico para clientes de exercício no contexto do fitness.

Palavras chave: Teoria da Autodeterminação, exercício, necessidades básicas, comportamentos interpessoais, instrutores de fitness. 


\section{Basic Needs in Portuguese Exercise Instructors Scale}

\section{INTRODUCTION}

Previous research has shown that when exercisers experience Basic Psychological Need (BPN) satisfaction, they are more likely to maintain the behavior (i.e., physical exercise practice) itself longer (Teixeira et al., 2012). However, to date, most of the research has only given attention to exercisers and has not taken into contemplation how exercise instructors experience satisfaction and frustration of BPN when interacting with gym practitioners (Edmunds, Ntoumanis, \& Duda, 2007). Since exercise professionals play an important role in adherence to regular exercise practice (Rodrigues et al., 2018) researchers should analyze exercise instructors' BPN experience. Till date, there has been no attempt in creating or validating a scale that measures BPN in fitness instructors. Therefore, in order to fill the gap in literature, we intend to validate a scale that taps into satisfaction and frustration of basic needs in exercise fitness instructors.

\section{Self-Determination Theory and Basic Psychological Needs}

Our study was grounded on the theoretical framework of Self-Determination Theory (SDT), since it explains how humans act as active beings in order to satisfy their BPN (Ryan \& Deci, 2017). In other words, satisfaction of the BPN is related to positive outcomes such as well-being, enjoyment), healthy eating in children (Girelli,
Manganelli, Alivernini, \& Lucidi, 2016), more self-determined motivation (Pardo, Castrillón, Pedreño, \& Moreno-Murcia, 2014), and contributes efficient functioning of individuals behaviors (Chen et al., 2015). In exercise context, several authors have shown that exercisers who feel that their BPN are being satisfied, entail positive consequences, such as well-being (Teixeira, Marques, \& Palmeira, 2018) and adherence (Rodrigues et al., 2018). In addition, results shown that perceived supporting interpersonal behaviors from peers (e.g., exercise professionals) are related to BPN satisfaction (Hernández, Mora, \& Rodríguez, 2018; Marholz, 2017; Silva et al., 2011). Thus, despite our search, few (or none) studies have analyzed BPN in exercise professionals when interacting with fitness exercisers.

According to SDT, there are three BPN: autonomy (i.e., the need to control his/her own behavior); competence (i.e., feeling efficient and skilled to advance and master new abilities), and; relatedness (i.e., person's need to interact emotionally with others). BPN satisfaction bears several positive outcomes, namely by contributing to physical and psychological development (Deci \& Ryan, 2000).

On the other hand, individuals may also perceive BPN frustration. Frustration of autonomy involves the experience of controlled behavior derived from selfimposed pressures. Competence Frustration refers to the feeling of self-doubt in one's 


\section{Rodrigues, F., Neiva, H.P., Marinho, D.A., Mendes, P., Teixeira, D.S., Cid, L., Monteiro, D.}

own capacity. Relatedness Frustration is associated with feelings of loneliness and social exclusion from others (Chen et al., 2015).

It is worth to mention that BPN satisfaction and frustration are two distinct constructs (Ryan \& Deci, 2017; Teixeira, Marques, \& Palmeira, 2018). Differences between needs' satisfaction and frustration may be the result of how the social environment interacts with the individual, and how the person experiences those behaviors. Rocchi and Pelletier (2018) found positive associations with BPN satisfaction and supporting behaviors, and with BPN frustration and thwarting interpersonal behaviors in sport coaches. Other authors found similar results, where autonomy support was related to BPN satisfaction (Balaguer, Castillo, Duda, 2008; CantúBerrueto et al., 2016; Pulido, Leo, Chamorro, \& García-Calvo, 2015). In exercise context, we hypothesize that exercise professionals experience of satisfaction will be related to increase supporting style when interacting with exercisers. However, this needs to be tested in exercise context, with fitness instructors in order to avoid biased conclusions.

\section{Gender differences in the exercise context}

According to SDT, BPN constructs are hypothesized to be universal, implying that there are no differences across age, gender and ethnicity (Ryan \& Deci, 2017). In addition, BPN satisfaction and frustration are important predictors in how individuals regulate their own motivation (Teixeira et al., 2018). However, according to our research, there are few studies who have analyzed measurement invariance between gender or other characteristic (e.g., age, cultural background) of the BPN constructs in exercise context. In addition, several studies found convergent results in measuring satisfaction of BPN. Rodrigues et al. (2018) found only differences in relatedness frustration between male and female exercisers. Other studies (e.g., Vlachopoulos, 2008) demonstrated that male and female exercisers experience BPN's satisfaction similarly. Therefore, more studies are needed since no study has ever tested BPN constructs in exercise professionals. In addition, a gap remains in the literature on how male and female fitness instructors experience BPN's satisfaction and/or frustration in an exercise context.

\section{BPN evaluation in Exercise Professionals}

According to Caspersen et al. (1985), physical activity, exercise and sport are similar but distinct concept. Physical activity is bodily movement through skeletal muscles, resulting in energy expenditure. Exercise incorporates all physical activity characteristics, thus it is planned, structured, and regularly repeated as a habit. Although sports encompass physical activity and exercise, it is also having a set of rules and 


\section{Basic Needs in Portuguese Exercise Instructors Scale}

excel in athlete's performance and skills. Several studies have analyzed BPN in individual's physical activity (e.g., Ntoumanis, 2012), in exercisers (e.g., Teixeira, Silva, \& Palmeira, 2018) and in athletes (e.g., Monteiro, Pelletier, Moutão, \& Cid, 2018). Thus, when considering "supervisors" (e.g., teachers, coaches, fitness professionals), studies are scarce. Therefore, it is important to examine BPN satisfaction and frustration in fitness professionals, since they are responsible for how individuals participate actively in physical exercise (Rodrigues et al., 2018).

There has been no attempt to analyze BPN satisfaction and frustration among exercise professionals. This may be due to the lack of a validate scale that taps into how fitness instructors experience satisfaction and frustration of autonomy, competence and relatedness during their interactions with gym and academy exercisers. Only recently, Chen et al. (2015) has created a scale, the Basic Psychological Need Satisfaction and Frustration Scale (BPNSFS), assessing satisfaction and frustration of all three needs. The scale was validated for the general population. This scale was translated in Portuguese by Cordeiro et al. (2016), with Portuguese students, showing measurement invariance. They suggest that this scale needs to be tested in other populations in the same context to test invariance.

\section{Current Research}

The aim of the present study is to address the limitations in analyzing BPN satisfaction and frustration in exercise professionals. Therefore, we intend to validate the BPNSFS (Chen et a., 2015) in fitness instructors. Afterwards, we will analyze the distinctiveness of BPN constructs and how they are related to own interpersonal behaviors. In addition, we will examine measurement invariance between gender and compare latent means of all factors between male and female exercise professionals.

\section{METHODS}

\section{Participants}

477 Portuguese exercise professionals working a gym or academy facilities (319 males, 158 females) between the ages of 18 and $73(M=34.10, S D=11.57)$ with professional experience that ranged from 0.5 to 41 years $(M=58.41, S D=68.91)$ participated in this study. With regard to the fitness activities, $15,7 \%$ were personal trainers, $50.5 \%$ were fitness instructors and $33.8 \%$ were group class instructors. In terms of academic education, exercise professionals had bachelor degree (47\%), master degree (39.6\%), doctoral degree $(2.1 \%)$ or post-graduate certification (20.2\%). For inclusion, participants needed to be licensed professionals with minimum of 6 months experience, aged over 18 years, and work as personal trainer, gym instructor or group class instructor at a gym or academy. 


\section{Rodrigues, F., Neiva, H.P., Marinho, D.A., Mendes, P., Teixeira, D.S., Cid, L., Monteiro, D.}

\section{Instruments}

Psychological Need Satisfaction and Frustration. Participants completed the Portuguese version of the Basic Psychological Need Satisfaction and Frustration Scale (it was translated and validated by the authors and was submitted for publication) in exercise context. This scale assesses their perceived BPN's satisfaction or frustration in exercise. This multidimensional questionnaire is split into six factors. Three factors consider the experience of BPN's satisfaction and three the BPN's frustration. The scale is composed of 24 items, six for each construct. The items received slight syntax adjustments to exercise professionals, using the stem "I prescribe exercise because..." These changes were made by four specialists in exercise psychology and syntax issues where corrected by four Portuguese teachers with higher degree. The participants indicated their agreement to each item through a 7point Likert-type scale that varied between 1 (totally disagree) and 7 (totally agree). Several previous studies (Chen et al., 2015; Cordeiro et al., 2016) showed acceptable internal consistency as well as construct validity.

\section{Interpersonal Behavior. Participants} completed the translated Portuguese version of the IBQ-SELF (it was translated and validated by the authors and was submitted for publication) measuring their own perceived behaviors when engaging with exercisers, using the stem "when I'm with my clients ....". Participants indicated their agreement with each item using a Likerttype scale ranging from 1 (completely disagree) to 7 (completely agree). This instrument consists of six subscales (Autonomy-Support, Competence Support, Relatedness Support, Autonomy Thwarting, Competence Thwarting, Relatedness Thwarting) tapping on their interpersonal behaviors when interacting with their clients. The data fit the model: $[\chi 2(237)=$ 1345.567, $\chi 2 / \mathrm{df}=5.68 ; \mathrm{B}-\mathrm{S} \mathrm{p}<.001, \mathrm{CFI}$ $=.918, \mathrm{TLI}=.907, \mathrm{SRMR}=.0412, \mathrm{RMSEA}$ $=.067(\mathrm{CI} 90 \%=.057, .077)]$, and internal consistency was acceptable in all factor $(>78)$.

\section{Procedure: data collection}

After approval from the Ethical Committee of Beira Interior University, with the registration number CE-UBI-pJ-2018044:ID683, the authors got directly in touch with exercise professionals through online research in different social media (e.g., LinkedIn, Facebook). Participants were asked to participate voluntary in this study. Study objectives were explained and they signed informed consent prior to data collection. Both informed consent and questionnaire were obtained through an online survey (i.e., surveymonkey.com). Participants received no monetary reward for their contribution, but were thanked for their participation. 


\section{Basic Needs in Portuguese Exercise Instructors Scale}

Statistical analysis:

A preliminary analysis of the data was performed, in order to verify normality, missing values, and outliers. Subsequently, to assess data fit (i.e., factorial validity), a Confirmatory Factor Analysis (CFA) using AMOS 23.0 was performed. CFA was performed through Maximum Likelihood method and measurement model adequacy verified by the Goodness-of-Fit indexes: Comparative Fit Index (CFI), Tucker-Lewis Index (TLI), Standard Mean Root Square Residual (SRMR), and Root Mean Square Error of Approximation (RMSEA), and its confidence interval $(90 \% \mathrm{CI})$. For these indexes, cut-off values suggested by several authors (e.g., Byrne, 2010; Hair, Black, Babin, \& Anderson, 2014; Marsh, Hau, \& Wen, 2004) were used. Specifically: CFI and TLI $\geq 0.90$, SRMR and RMSEA $\leq 0.8$. Internal consistency was analyzed through composite reliability and calculated by Raykov's formula (1997). Average Variance Extracted (AVE) was calculated to evaluate convergent validity, with cut-off $>.50$. Discriminant validity was achieved when construct AVE values were larger than the squared correlations (Hair et al., 2014).

\section{Nomological analysis:}

Correlations $(r)$ were evaluated to assess relationships among all study variables. The correlations were used to determine nomological validity with the IBQ-Self (Rocchi, Pelletier, Cheung, Baxter, \&
Beaudry, 2017) adapted to Portuguese by the authors.

\section{Multigroup analysis:}

Measurement invariance was performed according to several authors recommendations (Byrne, 2010; Cheung \& Rensvold, 2002), specifically: i) measurement model should represent a good fit in each of the groups; ii) configural, metric, scalar and residual invariance. Thus, according to some authors (e.g., Byrne, 2010; Cheung \& Rensvold, 2002), residual invariance is optional since it is very difficult to achieve especially in the field of social sciences, which englobes the exercise context. Invariance assumptions were verified through the differences of CFI $(\Delta \mathrm{CFI} \leq .01)$ in line with Cheung \& Rensvold (2002). Invariance models were evaluated using several recommendations (e.g., Chen, 2007), specifically: for metric invariance, change in SRMR ( $\triangle$ SRMR) of less than .030, and change in RMSEA (ARMSEA) of less than .015 would support model fit; for scalar invariance a change in SRMR ( $\triangle$ SRMR) of less than .010 and change in RMSEA ( $\triangle$ RMSEA) of less than .015 and would indicate good invariance.

\section{Latent mean differences analysis:}

Comparison between latent mean differences was only possible after the multigroup model confirmed invariance (Kline, 2016). Mean and covariance structure analyses were used to test for latent mean 


\section{Rodrigues, F., Neiva, H.P., Marinho, D.A., Mendes, P., Teixeira, D.S., Cid, L., Monteiro, D.}

differences between each need satisfaction and frustration construct. Latent mean values for the male sample was always constrained to zero, while it was freely estimated for the female sample. The $Z$ statistic was used to determine statistical significance between latent means. Cohen's $d$ criterion (1988) was calculated to obtain the correspondent effect size, following Kline's (2016) recommendations.

\section{RESULTS}

Preliminary analysis:

Missing values were less than $0.1 \%$. No univariate or multivariate outliers were identified. Descriptive analysis exhibited no violations of the univariate distribution, since Skewness and Kurtosis were contained between cut-off values, -2 to +2 and -7 to +7 , respectively (Byrne, 2010). However, a Bollen-Stine Bootstrap of 2000 samples was used, since the Mardia coefficients' value of 304.555 exceeded for multivariate normality (Byrne, 2010).

\section{Construct validity:}

Results support the original 24-item, 6 factors, model as shown in Table 1. The lowest factor loading was .58 in Competence Frustration, and the highest was .95 in autonomy satisfaction. For more details see Table 2.

Descriptive analysis is shown in Table 3. Results regarding composite reliability exhibited adjusted level (CR >.70). Convergent validity was achieved in all constructs, except competence frustration (.46), since AVE values were $<.50$ level (Hair et al., 2014). Competence frustration was retained to ensure the complete theory could be tested. According to the analysis, squared correlations between: AS-CS; ASRS; CS-RS; AF-CF; AF-RF; and CF-RF were higher than the AVE values ( $r>\mathrm{AVE}$ ), revealing discriminant validity problems.

\begin{tabular}{lccccccccc}
\hline \multicolumn{1}{l}{ Table 1. Comparisons of Goodness-of-fit indexes of the BPNSFS (24 items, 6 factor) between present study and others } \\
\hline & $\chi 2$ & $\mathrm{df}$ & $\chi 2 / \mathrm{df}$ & CFI & TLI & SRMR & RMSEA & RMSEA 90\% CI \\
\hline Original version $^{\mathrm{a}}$ & 372.71 & 231 & 1.61 & .97 & n.r. & .04 & .03 & n.r. \\
Japanese version $^{\mathrm{b}}$ & 645.03 & 237 & 2.72 & .90 & .89 & .055 & .055 & $.050-.061$ \\
Portuguese General version $^{\mathrm{c}}$ & 519.13 & 237 & 2.19 & .95 & n.r. & .06 & .05 & n.r. \\
Portuguese Exercise version $^{\mathrm{d}}$ & 571.796 & 237 & 2.41 & .94 & .94 & .038 & .047 & $.042-.052$ \\
Present study & 1096.796 & 237 & 4.63 & .93 & .918 & .037 & .079 & $.069-.089$ \\
\hline
\end{tabular}

Note: $\chi^{2}=$ chi-square; $d f=$ degrees of freedom; $\chi^{2} / d f=$ normative chi-square; CFI = comparative fit index; TLI $=$ Tucker-Lewis index; SRMR $=$ standardized root mean square residual; RMSEA $=$ root mean squared error of approximation; $90 \% \mathrm{CI}=$ confidence interval of RSMEA; n.r. = not reported; ${ }^{\mathrm{a}}$ Chen et al. (2015); ${ }^{\mathrm{b}}$ Nishimura \& Suzuki (2016); ${ }^{\mathrm{c}}$ Cordeiro et al. (2015); ${ }^{\mathrm{d}}$ Rodrigues et al. (it was translated and validated by the authors and was submitted for publication). 


\section{Rodrigues, F., Neiva, H.P., Marinho, D.A., Mendes, P., Teixeira, D.S., Cid, L., Monteiro, D.}

\begin{tabular}{|c|c|c|}
\hline & $\lambda$ & $\lambda^{2}$ \\
\hline \multicolumn{3}{|c|}{ Autonomy Satisfaction } \\
\hline Item 1 & .80 & .65 \\
\hline Item 7 & .89 & .79 \\
\hline Item 13 & .95 & .90 \\
\hline Item 19 & .94 & .89 \\
\hline \multicolumn{3}{|c|}{ Autonomy Frustration } \\
\hline Item 2 & .65 & .43 \\
\hline Item 8 & .74 & .55 \\
\hline Item 14 & .73 & .53 \\
\hline Item 20 & .79 & .63 \\
\hline \multicolumn{3}{|c|}{ Competence Satisfaction } \\
\hline Item 3 & .92 & .84 \\
\hline Item 9 & .92 & .84 \\
\hline Item 15 & .94 & .88 \\
\hline Item 21 & .92 & .84 \\
\hline \multicolumn{3}{|c|}{ Competence Frustration } \\
\hline Item 4 & .58 & .33 \\
\hline Item 10 & .66 & .44 \\
\hline Item 16 & .77 & .59 \\
\hline Item 22 & .68 & .46 \\
\hline \multicolumn{3}{|c|}{ Relatedness Satisfaction } \\
\hline Item 5 & .93 & .87 \\
\hline Item 11 & .92 & .85 \\
\hline Item 17 & .95 & .90 \\
\hline Item 23 & .94 & .89 \\
\hline \multicolumn{3}{|c|}{ Relatedness Frustration } \\
\hline Item 6 & .73 & .53 \\
\hline Item 12 & .73 & .53 \\
\hline Item 18 & .71 & .51 \\
\hline Item 24 & .71 & .50 \\
\hline
\end{tabular}

\begin{tabular}{|c|c|c|c|c|c|c|c|c|c|c|c|c|c|c|c|}
\hline Factors & Mean & SD & Range & 1 & 2 & 3 & 4 & 5 & 6 & 7 & 8 & 9 & 10 & 11 & 12 \\
\hline 1. Aut. Satisfaction & 4.88 & 1.17 & $1-7$ & 1 & & & & & & & & & & & \\
\hline 2. Aut. Frustration & 1.63 & .66 & $1-7$ & $-.63^{* *}$ & 1 & & & & & & & & & & \\
\hline 3. Comp. Satisfaction & 4.85 & 1.18 & $1-7$ & $.92^{* *}$ & $-.58^{* *}$ & 1 & & & & & & & & & \\
\hline 4. Comp. Frustration & 1.44 & .51 & $1-7$ & $-.59^{* *}$ & $.69^{* *}$ & $-.60^{* *}$ & 1 & & & & & & & & \\
\hline 5. Rel. Satisfaction & 5.02 & 1.09 & $1-7$ & $.95^{* *}$ & $-.60^{* *}$ & $.95^{* *}$ & $-.60^{* *}$ & 1 & & & & & & & \\
\hline 6. Rel. Frustration & 1.52 & .60 & $1-7$ & $-.65^{* *}$ & $.60^{* *}$ & $-.59^{* *}$ & $.63^{* *}$ & $-.68^{* * *}$ & 1 & & & & & & \\
\hline 7. Aut. Support & 5.29 & .96 & $1-7$ & .09 & -.14 & .10 & $-.18^{*}$ & .07 & -.15 & 1 & & & & & \\
\hline 8. Aut. Thwarting & 3.44 & 1.29 & $1-7$ & -.04 & $.27^{* *}$ & -.04 & $.24^{* *}$ & -.07 & $.16^{*}$ & $-.20^{*}$ & 1 & & & & \\
\hline 9. Comp. Support & 6.43 & .62 & $1-7$ & .11 & $-.29^{* *}$ & .13 & $-.33^{* *}$ & .14 & $-.27^{* *}$ & $.24^{* *}$ & -.15 & 1 & & & \\
\hline 10. Comp. Thwarting & 2.02 & .83 & $1-7$ & -.15 & $.27^{* *}$ & $-.17^{*}$ & $.33^{* *}$ & -.15 & $.17^{*}$ & $-.16^{*}$ & $.41^{* *}$ & $-.27^{* *}$ & 1 & & \\
\hline 11. Relat. Support & 6.18 & .64 & $1-7$ & $.21^{* *}$ & $-.46^{* *}$ & $.26^{* *}$ & $-.44^{* *}$ & $.21^{* *}$ & $-.29^{* *}$ & $.40^{* *}$ & $-.24^{* *}$ & $.59^{* *}$ & $.35^{* *}$ & 1 & \\
\hline 12. Relat. Thwarting & 1.47 & .69 & $1-7$ & -.11 & $.32^{* * *}$ & -.12 & $.41^{* *}$ & -.12 & $.25^{* *}$ & $-.25^{* *}$ & .15 & $-.48^{* * *}$ & $.34^{* *}$ & $-.55^{* *}$ & 1 \\
\hline
\end{tabular}

Table 3. Mean (M), Standard Deviations (SD), Composite Reliability (CR), Average Variance Extracted (AVE) and correlations $(r)$

\begin{tabular}{lcccccccccc}
\hline & Mean & SD & CR & AVE & 1 & 2 & 3 & 4 & 5 & 6 \\
\hline Autonomy Satisfaction & 4.88 & 1.17 & .94 & .81 & 1 & & & & & \\
Autonomy Frustration & 1.63 & .66 & .82 & .54 & .48 & 1 & & & & \\
Competence Satisfaction & 4.85 & 1.18 & .96 & .85 & .94 & .42 & 1 & & & \\
Competence Frustration & 1.44 & .51 & .77 & .46 & .42 & .73 & .46 & 1 & & \\
Relatedness Satisfaction & 5.02 & 1.09 & .97 & .88 & .96 & .45 & .95 & .46 & 1 & \\
Relatedness Frustration & 1.52 & .60 & .81 & .52 & .47 & .62 & .39 & .68 & .55 & 1 \\
\hline
\end{tabular}




\section{Basic Needs in Portuguese Exercise Instructors Scale}

Nomological validity:

According to our results, moderate positive associations were found between BPN satisfaction and supporting interpersonal behaviors, and negative associations (some of them significant) with thwarting behaviors. On the other hand, BPN frustration was negatively and significantly associated with supporting behaviors, and significantly positive associated with autonomy-thwarting, competencethwarting and relatedness-thwarting. These results support the scales nomological validity. For more detail see Table 4.

Multigroup analysis:
Regarding Table 5, analysis revealed that the measurement model is invariant between gender based on recommended criteria (Byrne, 2010; Cheung \& Rensvold, 2002), namely:: i) measurement model fit data in each group: male $[\chi 2(237)=928.191, \chi 2 / \mathrm{df}=$ 3.92; B-S $\mathrm{p}<.001$, CFI $=.917$, TLI $=.903$, $\mathrm{SRMR}=.048, \mathrm{RMSEA}=.080(\mathrm{CI} 90 \%=.075, .085)$; and female $[\chi 2(237)=547.763, \chi 2 / \mathrm{df}=2.31 ; \mathrm{B}-\mathrm{S} \mathrm{p}$ $=.004, \mathrm{CFI}=.922, \mathrm{TLI}=.909, \mathrm{SRMR}=.043$, RMSEA $=.081($ CI90\% $=.071, .091)]$; ii $)$ variables invariance were confirmed: configural, metric, scalar and residual. All values were below cut-off values proposed by Chen's (2007) recommendations for measurement invariance.

Table 5. Gender invariance models

\begin{tabular}{|c|c|c|c|c|c|c|c|c|c|c|c|}
\hline Invariance & $\chi^{2}$ & $\mathrm{df}$ & $\Delta \chi^{2}$ & $\Delta \mathrm{df}$ & $p$ & CFI & $\Delta \mathrm{CFI}$ & SRMR & $\begin{array}{c}\Delta \mathrm{SRM} \\
\mathrm{R}\end{array}$ & $\begin{array}{c}\text { RMSE } \\
\text { A }\end{array}$ & $\triangle \mathrm{RMSEA}$ \\
\hline Configural & 1476.146 & 474 & - & - & - & 0.918 & - & .0439 & - & .067 & - \\
\hline Metric & 1488.626 & 492 & 12.48 & 18 & .106 & 0.919 & .001 & .0401 & .0038 & .065 & .002 \\
\hline Structural & 1529.662 & 513 & 53.516 & 39 & $<0.001$ & 0.917 & .002 & .0424 & .0015 & .065 & .002 \\
\hline Residual & 1615.202 & 537 & 139.056 & 63 & $<0.001$ & 0.912 & .006 & .0438 & .0001 & .065 & .002 \\
\hline
\end{tabular}

Note. $\chi^{2}=$ chi-square; $\mathrm{df}=$ degrees of freedom; $\Delta \chi^{2}=$ differences in the value of chi-squared; $\Delta \mathrm{df}=$ differences in the degrees of freedom; CFI = Comparative Fit Index; $\Delta$ CFI = differences in the value of the Comparative Fit Index; CI $=$ configural invariance; $\mathrm{MI}=$ measurement invariance; $\mathrm{SI}=$ scale invariance; $\mathrm{RI}=$ residual invariance 



\section{Rodrigues, F., Neiva, H.P., Marinho, D.A., Mendes, P., Teixeira, D.S., Cid, L., Monteiro, D.}

Latent mean differences between male and

female exercisers:

Results related to differences in latent means between gender exercise professionals regarding BPN constructs are synthetized in Table 6. Our analysis revealed no differences between satisfaction and frustration constructs in male and female participants. All magnitude effects were trivial across constructs between male and female participants $(<0.19)$.

Table 6. Latent mean differences between gender on basic psychological needs constructs

\begin{tabular}{lcccc}
\hline & $\begin{array}{c}\text { Differen } \\
\text { ce }\end{array}$ & $z$ & $p$ & $d$ \\
\hline Autonomy & -.105 & - & .27 & .11 \\
Satisfaction & & 1.092 & 5 & 1 \\
Competence & -.039 & -.906 & .36 & .00 \\
Satisfaction & & & 5 & 7 \\
Relatedness & -.001 & -.012 & .99 & .13 \\
Satisfaction & & & 0 & 1 \\
Autonomy & -.029 & -.727 & .46 & .08 \\
Frustration & & - & .17 & 0 \\
Competence & -.137 & 1.371 & 0 & 0 \\
Frustration & & 1.910 & .05 & .18 \\
Relatedness & .128 & 1.910 & 4 \\
Frustration & & & &
\end{tabular}

\section{DISCUSSION}

This study's aim was to validate the BPNSFS into exercise instructors and test its invariance across gender. In addition, we analyzed nomological validity with interpersonal behaviors, based on the theoretical framework of SDT (Ryan \& Deci, 2017).

Factorial validity
CFA performed on the 24-item scale extracted six highly correlated but distinct factors, tapping in satisfaction and frustration of autonomy, competence and relatedness. These results were expected since other studies found similar outcomes in Portuguese participants (Cordeiro et al., 2016). Results confirmed that all factors were internally consistent, since values of composite reliability were $>0.7$ (Hair et al., 2014). It is worth to mention that no item had factor loading below .50.

The factors displayed values of AVE above recommended, except for competence frustration (.46). Several studies using the BPNSFS have also identified problems with this factor (Chen et al., 2015; Nishimura \& Suzuki, 2016). This would suggest that items measuring competence frustration are not adjusted. However, according to other authors (Byrne, 2010; Hair et al., 2014), if the factor weights are significant in its respective factor, they should be maintained. Therefore, and since no cross-loadings were detected, our results suggest good convergent validity of all factors.

Although some discriminant validity issues were found in our analysis, satisfaction of each need was negatively correlated with BPN frustration factors (all p's $<.05$ ). Likewise, covariance among satisfaction factors was positive and significant. The same was verified regarding frustration factors. This suggests that statistically, these 
factors are distinguishable (Hair et al., 2014).

In addition, theoretically these constructs are indeed different, according to SDT proposed by Ryan and Deci (2017). Citing these authors: "each (need) is independently important, ... In addition, SDT sees these three basic needs as interdependent." (p. 248). As stressed by these authors: "needs vary independently (e.g., one feels incompetent while performing a valued activity), SDT expects that the three needs will tend to be highly intercorrelated, especially in measurements that aggregate satisfaction or frustration experience in a domain..." (p. 249).

Our model exhibit satisfactory fit to the data, following several authors (Byrne et al., 2010; Hair et al., 2014; Marsh et al., 2004). recommendations. Other studies who have analyzed the BPNSFS (Cordeiro et al., 2016; Chen et al., 2015; Nishimura \& Suzuki, 2016) found similar results. Therefore, this scale is applicable in different domains and cultural backgrounds.

\section{Nomological Validity}

Results showed satisfactory correlations between satisfaction and frustration of BPN and interpersonal behaviors constructs. BPN satisfaction exhibited positive associations with supporting behaviors and negative associations with autonomy, competence and relatedness thwarting. Moreover, BPN's frustration was positively associated with thwarting interpersonal behaviors and negatively related to autonomy, competence and relatedness support. Rocchi et al. (2018) found similar results relating BPN constructs with behavioral regulations. These authors exhibited positive associations of BPN satisfaction with more autonomous forms of motivation. Moreover, BPN's frustration was positively associated with more controlled regulations of motivation. In addition, relatedness support had the strongest and most significant correlations with all BPN satisfaction constructs. These may be related to the fact that exercise professionals who feel their needs being satisfied are more likely to experience more positive and supporting social interactions with exercisers. However, this needs to be tested for proper validation.

\section{Measurement Invariance}

Results support measurement invariance of BPNSFSE for male and female exercise professionals since all invariance assumptions were met, following Byrne (2010), and Chen (2007) recommendations. Findings indicate configural, metric, scalar and residual invariance. Other studies analyzing measurement invariance of this scale found similar results (Chen et al., 2015). These results are in accordance to SDT assumption, which they refer that BPN satisfaction and frustration are universal, independent of cultural background, age, gender, ethnicity, and context (Ryan \& Deci, 2017). 


\section{Rodrigues, F., Neiva, H.P., Marinho, D.A., Mendes, P., Teixeira, D.S., Cid, L., Monteiro, D.}

\section{Latent mean differences}

Regarding latent means between gender, our results found no significant differences. In addition, magnitude effects were trivial $(<.19)$ in all factors. This demonstrates the dimensionality of BPN constructs. This mean that male and female exercise instructors experience in the same way basic psychological needs when interacting with exercise participants. Previous studies using the same scale found similar results (the Portuguese exercisers version which, was translated and validated by the authors and was submitted for publication) except for relatedness frustration factor. However, these authors report trivial effect in this construct, and suggest that male exercisers may experience differently from female based on how they perceive interpersonal behaviors from the social context. It is worth to mention that this is the first study analyzing measurement invariance between male and female exercise instructors. Therefore, results need to interpreted with caution.

\section{LIMITATIONS}

Despite our research being based on a strong theoretical framework, the present studies show some limitations. The present research was applied in Portuguese exercise instructors. Therefore, more cultural analysis is warranted for its applicability in the exercise domain. In addition, this study is cross-cultural in its nature. Future studies should analyze the scale in a longitudinal way for time invariance confirmation. We suspect that exercise professionals may fell satisfaction and frustration of needs differently across professional experience (e.g., years). Lastly, future investigations should analyze BPN constructs with behavioral regulations in exercise domain with instructors. Rocchi et al. (2018) found positive associations between BPN satisfaction and more autonomous forms of motivation, and positive associations between BPN frustration and more controlled forms in sports coaches. However, this needs to be tested in exercise context, with exercise instructors, given that they are poorly studied.

Considering our analysis, these results support the applicability of the BPNSFS in exercise professionals, adding new evidence for construct distinctiveness of BPN satisfaction and frustration, based on SDT framework. The present work reinforces the importance to analysing basic needs satisfaction and frustration in exercise professionals, in order to understand how they behave in supporting and thwarting interpersonal behaviors. BPNSFS is reliable in measuring feelings of basic psychological needs in Portuguese exercise instructors. This scale needs further analysis in order to test its applicability in other domains. 


\section{PRACTICAL APLICATIONS}

This study is up most important since this scale analyzes how exercise instructors experience basic psychological need satisfaction or frustration when prescribing exercise. In addition, results showed that BPN satisfaction are positively related to supporting interpersonal behaviors. Therefore, knowing how they feel when working at a gym or academy, can be related to perceived supporting behaviors from fitness exercisers. This association is relevant since perceived support behaviors by exercisers are predictors BPN satisfaction in individuals and adherence to physical exercise practice (Edmunds et al., 2007; Rodrigues et al., 2018). In addition, this sequence based on SDT shows that perceived supporting interpersonal behaviors by individuals are positively related to physical exercise practice (Moreno-Murcia et al., 2016).

\section{REFERENCES}

1. Balaguer, I., Castillo, I., Duda, J.L. (2008). Apoyo a la autonomía, satisfacción del as necesidades, motivación y bienestar en deportista de competición: un análisis de la teoría de la autodeterminación. Revista de Psicología del Deporte, 17(1), 123-139.

2. Byrne, B. (2010). Structural equation modeling with AMOS. Basic concepts, applications, and programming (2nd ed.). New York: Taylor \& Francis Group, LLC. ISBN: 978-0805863734
3. Cantú-Berrueto, A., Castillo, I., LópezWalle, J., Tristán, J., Balaguer, I. (2016). Estilo interpersonal del entrenador, necesidades psicológicas básicas $\mathrm{y}$ motivación: un estudio en futebolistas unversitarios mexicanos. Revista Iberoamericana de Psicología del ejercicio y el deporte, 11(2), 263-270. Doi: 311145841011

4. Caspersen, C., Powell, K., Christenson, G. (1985). Physical activity, exercise, and physical fitness: definitions and distinctions for health-related research. Public Health Report, 100(2), 126-131.

5. Chen, B., Vansteenkiste, M., Beyers, W., Boone, L., Deci, E., ... Verstuyf, J. (2015). Basic psychological need satisfaction, need frustration, and need strength across four cultures. Motivation \& Emotion, 39(2), 216-236. Doi: 10.1007/s11031-014-9450-1

6. Chen, F. (2007). Sensitivity of Goodness of Fit Indexes to Lack of Measurement Invariance. Structural Equation Modeling, 14(3), 464-504. Doi: $10.1080 / 1070551070131834$

7. Cheung, G., \& Rensvold, R. (2002). Evaluating goodness-of-fit indexes for testing measurement invariance. Structural Equation Modeling, 9(2), 233-255.

Doi:

\subsection{7/S15328007SEM0902 5}

8. Cohen, J. (1988). Statistical power analysis for the behavioural sciences $\left(2^{\text {nd }} e d\right)$. Hillsdale, NJ: Lawrence Earlbaum Associates. 


\section{Rodrigues, F., Neiva, H.P., Marinho, D.A., Mendes, P., Teixeira, D.S., Cid, L., Monteiro, D.}

9. Cohen, J. (1992). A power primer. Psychological Bulletin, 112(1), 155159. Doi: $10.1037 / 0033-2909.112 .1 .155$

10. Cordeiro, P., Paixão, P., Lens, W., Lacante, M., \& Luyckx, K. (2016). The Portuguese validation of the Basic Psychological Need Satisfaction and Frustration Scale: concurrent and longitudinal relations to well-being and ill-being. Psychologica Belgica, 56(3), 193-209. Doi: 10.5334/pb.252

11. Deci, E., \& Ryan, R. (2000). The "What" and "Why" of Goal Pursuits: Human Needs and the SelfDetermination of Behavior. Psychology Inquiry, 11(4), 227-268. Doi: 10.1207/S15327965PLI1104_01

12. Edmunds, J., Ntoumanis, N., \& Duda, J. (2007). Adherence and well-being in overweight and obese patients referred to an exercise on prescription scheme: a self-determination theory perspective. Psychology of Sport and Exercise, 8(5), 722-740.

Doi:

10.1016/j.psychsport.2006.07.006

13. Girelli, L., Manganelli, S., Alivernini, F., \& Lucidi, F. (2016). A Selfdetermination theory based intervention to promote healthy eating and physical activity in school -aged children. Cuadernos de Psicología del Deporte, 16(3), 13-20.

14. Hair, J., Black, W., Babin, B. \& Anderson, R. (2014). Multivariate Data Analysis (7th ed.). New Jersey: Pearson
Educational, Inc. ISBN: 9780138132637

15. Hernández, J., Mora, P., \& Rodríguez, M. (2018). Entrenar a los padres, mejorar el equipo. La experiencia de la LIGA BRAVE. Revista de Psicología Aplicada al Deporte y al Ejercicio Fisico, 3(7), 1-13. Doi: 10.5093/rpadef2018a 1

16. Kline, R. (2016). Principles and practice of structural equation modelling ( $3^{\text {rd }}$ ed.). New York, The Guildford Press. ISBN: 9781462523344

17. Marholz, P. (2017). "no todo es Balón”. Implicando positivamente a los padres en la prática del fútbol en etapa formativa. Revista de Psicología Aplicada al Deporte y al Ejercicio Físico, 2(e9), 1-10. Doi: 10.5093/rpadef2017a9

18. Marsh, H., Hau, K., \& Wen, Z. (2004). In search of golden rules: comment on hypothesis testing approaches to setting cutoff values for fit indexes and dangers in overgeneralizing $\mathrm{Hu}$ and Bentler's (1999) findings. Structural Equation Modeling, 11(3), 320-341. Doi: 10.1207.s15328007sem1103_2

19. Monteiro, D., Pelletier, L.G., Moutão, J., \& Cid, L. (2018). Examining the motivational determinants of enjoyment and the intention to continue of persistent competitive swimmers. International Journal of Sport 
Psychology, 6(1), $49 . \quad$ Doi: 10.7352/IJSP.2018.49

20. Moreno-Murcia, J., Belando, N., Huéscar, E., \& Torres, M. (2016). Social support, physical exercise and life satisfaction in women. Revista Latinoamericana de Psycología, 49(3), 194-202.

Doi: 10.1016/j.rlp.2016.08.002

21. Nishimura, T., \& Suzuki, T. (2016). Basic Psychological Need Satisfaction and Frustration in Japan: Controlling for the Big Five Personality Traits. Japanese Psychological Research, 58(4), 320-331. Doi: 10.111/jpr.12131

22. Ntoumanis, N. (2012). A selfdetermination theory perspective on motivation in sport and physical education: current trends and possible future research directions. Motivation in Sport and Exercise, 3, 91-128.

23. Pardo, P., Castrillón, F., Pedreño, N., \& Moreno-Murcia, J. (2014). Selfdetermination motivation in elderly practitioners of physical exercise. Cuadernos de Psicología del Deporte, 14(3), 149-156. Doi: 10.4321/S157884232014000300016

24. Pulido, J., Leo, F., Chamorro, J., \& García-Calvo, T. (2015). ¿Apoyan los entrenadores la motivación de sus deportistas? Diferencias en la percepción del comportamiento. Revista de Psicología del Deporte, 24(1), 139145.
25. Raykov, T. (1997). Estimation of composite reliability for congeneric measures. Applied Psychological Measurement, 21(2), 173-184. Doi: $10.1177 / 01466216970212006$

26. Rocchi, M., \& Pelletier, L. (2018). How coaches' reported behavior align athletes' perceptions? The role of coaches' motivation and the consequences for the athletes' psychological needs in sport. Journal of Sport, Exercise, and Performance Psychology, 7(2), 141-154. Doi: 10.1037/spy0000116

27. Rocchi, M., Pelletier, L., Cheung, S., Baxter, D., \& Beaudry, S. (2017). Assessing need-supportive and needthwarting interpersonal behaviours: The Interpersonal Behaviours Questionnaire (IBQ). Personality and Individual Differences, 104, 423-433. Doi: 10.1016/j.paid.2016.08.034

28. Rodrigues, F., Bento, T., Cid, L., Neiva, H.P., Teixeira, D. S., Moutão, J., Marinho, D. A., \& Monteiro, D. (2018). Can interpersonal behavior influence the persistence and adherence to physical exercise practice in adults? A systematic review. Frontiers in Psychology. Doi: 10.3389/fpsyg.2018.02141

29. Ryan, R. \& Deci, E. (2017). Selfdetermination theory. Basic Psychological Needs in Motivation, Development, and Wellness. New York, NY: Guildford Press. ISBN: 9781462528769 
Rodrigues, F., Neiva, H.P., Marinho, D.A., Mendes, P., Teixeira, D.S., Cid, L., Monteiro, D.

30. Silva, M., Markland, D., Carraça, E., Vieira, P., Coutinho, S., ... Teixeira, P. (2011). Exercise autonomous motivation predicts 3-ye weight loss in women. Medicine \& Science in Sports \& Exercise, 43(4), 728-737. Doi: 10.1249/MSSS.0b013e3181f3818f

31. Teixeira, P., Carraça, E., Markland, D., Silva, M., \& Ryan, R. (2012). Exercise, physical activity, and self-determination theory: a systematic review. International Journal of Behavioral Nutrition and Physical Activity, 9(78), 1-30. Doi: 10.1186/1479-5868-9-78.

1. Teixeira, D., Marques, D., \& Palmeira, A. (2018). Associations between affect, basic psychological needs and motivation in physical activity contexts: systematic review and meta-analysis. Revista Iberoamericana de Psicología del ejercicio y el deporte, 13(2), 225233.

2. Teixeira, D., Silva, M., \& Palmeira, A. (2018). How does frustration make you feel? A motivational analysis in exercise context. Motivation and Emotion, 1-10. Doi: $\quad$ 10.1007/s11031-018-96906Vlachopoulos, S. (2008). The Basic Psychological Needs in Exercise Scale: Measurement invariance over gender. Structural Equation Modeling, 15(1), 144-135.

Doi:

$10.1080 / 1070551070175839$ 